\section{Soil Moisture, Forage, and Beef Production Benefits from Gambel Oak Control in Southwestern Colorado}

\section{ROBERT W. MARQUISS}

Assistant Professor of Range Science, San Juan Basin Branch Station, Colorado State University, Hesperus.

\section{Highlight}

Controlling Gambel oak and other brushy species with herbicides can produce benefits to the stockman. Increased forage and becf production are products of a good brush control practice. A high percentage of oak control is necessary to offset regrowth by sprouting. Soil moisture was significantly increased in the top five feet of soil during the summer months by controlling the oak. Forage production was doubled with a five-year period. Animal weight gains per acre nearly doubled as a result of brush control on Gambel oak rangeland.

Gambel oak (Quercus gambelii) is an important component of several million acres of foothill rangelands in Arizona, Colorado, Nevada, New Mexico, and Utah. Gambel oak grows throughout the Ponderosa pine zone and in association with pinyon pine and juniper at its lower clevation limits of 7,000 feet, and with aspen and spruce at its upper elevation limits of 10,000 feet (Christensen, 1949; Brown, 1958 and Tew, 1966).

The value of Gambel oak on rangelands is relatively unknown. Forage production under the oak has been reported as being comparable to surrounding openings (Brown, 1958). Other studies in southwestern Colorado have indicated significant increases in herbage yields on oak rangelands after treatment with herbicides (Astatke, 1967; Jefferies and Norris, 1965; Marquiss, 1969). Soil mois-

${ }^{1}$ Published with the approval of the Director of the Colorado State University Experiment Station as Scientific Series Paper No. 1642. Received May 1, 1971. ture studies have indicated that evapotranspiration losses from Gambel oak sites are significant. Tew (1966) in Utah, reported that, in years of normal rainfall, approximately a foot of water is extracted from the upper eight feet of soil during a growing season.

Patchy grazing is a problem on rangelands that possess intermixed thin and thick stands of trees or brushy species. Johnson (1953) indicated grassland parks received heavier grazing than open timbered areas, and heavily timbered areas were rarely grazed in the Ponderosa forests. Irregular patterns of grazing use were evident regardless of the grazing intensity. Livestock grazing oak rangelands tend to overgraze open areas and graze only lightly under the oak (Jefferies and Norris, 1965).

\section{Soil Moisture Studies}

\section{Methods}

Soil moisture determinations were taken from a Gambel oak-grass type range during four summer seasons (1967 through 1970). The study sites included open areas between oak clumps, undisturbed oak clumps, and 100 percent controlled oak. Determinations after 1967 included an oak sprout site that had been treated three consecutive years with $2,4,5-\mathrm{TP}^{2}$, where $80-90$ percent of the crown was killed and root sprouts were abundant.

Four replicated sampling sites were established for each treatment. Sampling dates were at two-week intervals during the summer months of each of the four consecutive years. Samples were collected with a Veihmeyer tube at one-foot intervals to a depth of five feet. Soil samples were dried at $105 \mathrm{C}$ and reported as percentage moisture loss on a dry weight basis. Average precipitation for respective months of May through September 1967 through 1970 was $0.83,1.37,2.00,2.26$, and 2.11 .

\section{Results}

A significant increase in soil moisture was observed where oak was totally controlled. The largest differences of soil moisture between treatments occurred during the mid-summer months (Fig. 1).

2 2-(2,4,5-Trichlorophenoxy) propionic acid. 

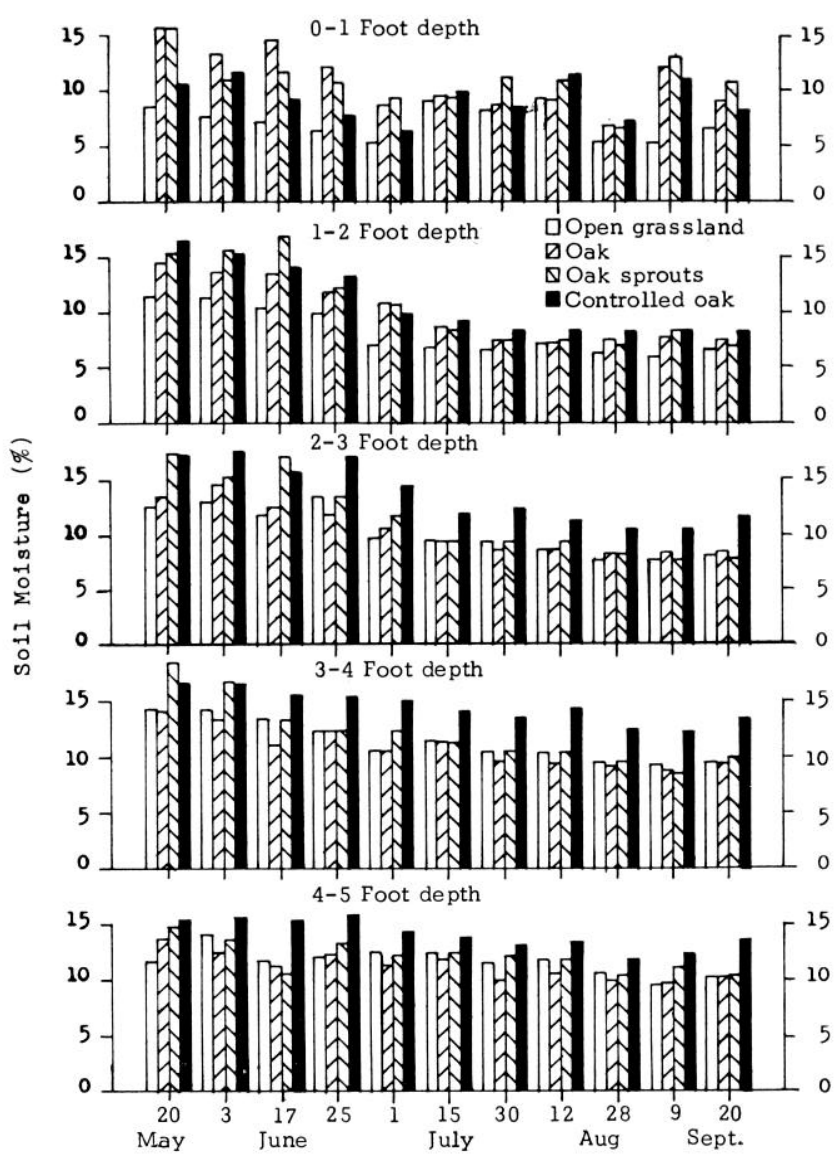

Fig. 1. Percentage soil moisture taken at five depths, four sites and four summer seasons on Gambel oak rangeland in southwestern Colorado.

The soil moisture differences were greatest from the 2- to 5-ft depths. Small differences and nearly equal percentages of soil moisture occurred from the 1- to 2-ft depth in both treated and untreated plots. Below the $2-\mathrm{ft}$ depth, increases in soil moisture were notably higher for effectively treated oak.

Table 1. Mean soil moisture (\%) among four sites at five depths on Gambel oak rangeland (1967-1970).

\begin{tabular}{ccrrrr}
\hline \hline & \multicolumn{5}{c}{ Sample site } \\
\cline { 2 - 5 } $\begin{array}{c}\text { Sample } \\
\text { depth }\end{array}$ & Open & Oak & $\begin{array}{c}\text { Oak } \\
\text { sprouts }\end{array}$ & $\begin{array}{c}\text { Con- } \\
\text { trolled } \\
\text { oak }\end{array}$ & $\begin{array}{c}\text { Depth } \\
\text { mean }\end{array}$ \\
\hline $0-1 \mathrm{ft}$ & 7.37 & 10.52 & 10.69 & 9.32 & $9.45^{1}$ \\
$1-2 \mathrm{ft}$ & 7.94 & 9.61 & 9.63 & 10.46 & $9.45 \mathrm{a}$ \\
$2-3 \mathrm{ft}$ & 9.68 & 9.94 & 10.57 & 13.13 & $10.89 \mathrm{~b}$ \\
$3-4 \mathrm{ft}$ & 11.01 & 10.31 & 11.42 & 14.36 & $11.83 \mathrm{bc}$ \\
$4-5 \mathrm{ft}$ & 11.79 & 10.86 & 12.06 & 13.71 & $12.13 \mathrm{c}$ \\
Mean & $9.56 \mathrm{x}$ & $10.25 \mathrm{x}$ & $10.88 \mathrm{x}$ & $12.20 \mathrm{y}$ & \\
\hline
\end{tabular}

${ }^{1}$ Means followed by the same letter are not significantly different at the 5 percent protection level.

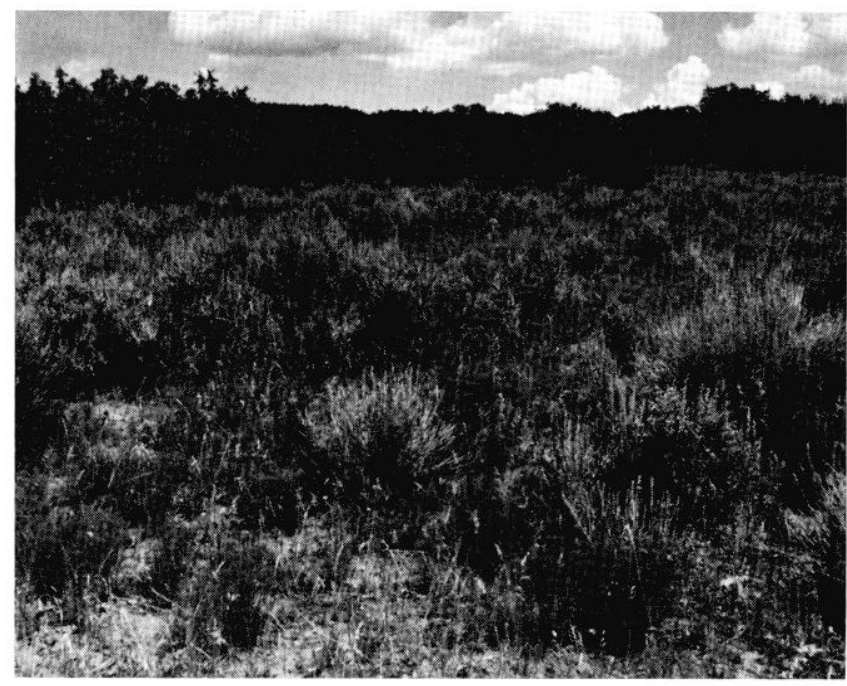

FIG. 2. Sagebrush, rabbitbrush, and oakbrush in the non-treated pasture (1969 photo).

Significantly greater soil moisture was found on totally controlled plots compared to non-treated oak sites (Table 1). The studies conducted after 1967, including an oak sprout site, still showed real differences of soil moisture at the 2- to 5-foot depth where all the oak stems had been successfully controlled.

\section{Forage Production and Grazing Studies}

\section{Methods}

Two pastures, each approximately 25 acres in size, were used as a paired plot grazing study. The vegetation types in each pasture were open grassland, sagebrush-grass, and oak-grass. Data on plant composition, soil depth, and terrain indicate the pastures are very similar. One pasture was left as untreated, the other was treated with herbicides to kill the dominant brush species. Both pastures were grazed moderately (near 50\%) during the period of the studies.

The history of herbicide treatments in the brush control pasture includes aerial spraying of sagebrush with 2,4- $\mathrm{D}^{3}$ in 1965 and spraying the oak with 2,4,5-TP and picloram ${ }^{4}$ mixture in 1966 and again in 1969. Although brush species were not totally killed, an estimated $95 \%$ of the sagebrush and $80 \%$ of the oak were controlled by these applications.

Forage production was determined by clipping the forage from caged plots, randomly placed within each vegetation type. Utilization was determined by double sampling based upon clipping and estimates of grazed and ungrazed plots.

Animal response was determined by grazing yearling steers during the mid-summer months. Initial weight of the steers was approximately 550 to 600 pounds. Pastures were utilized to approximately $50 \%$ each year. Livestock gains were based on average gain per day and on the

${ }^{4} 4$-amino-3,5,6-trichloro-picolonic acid. 


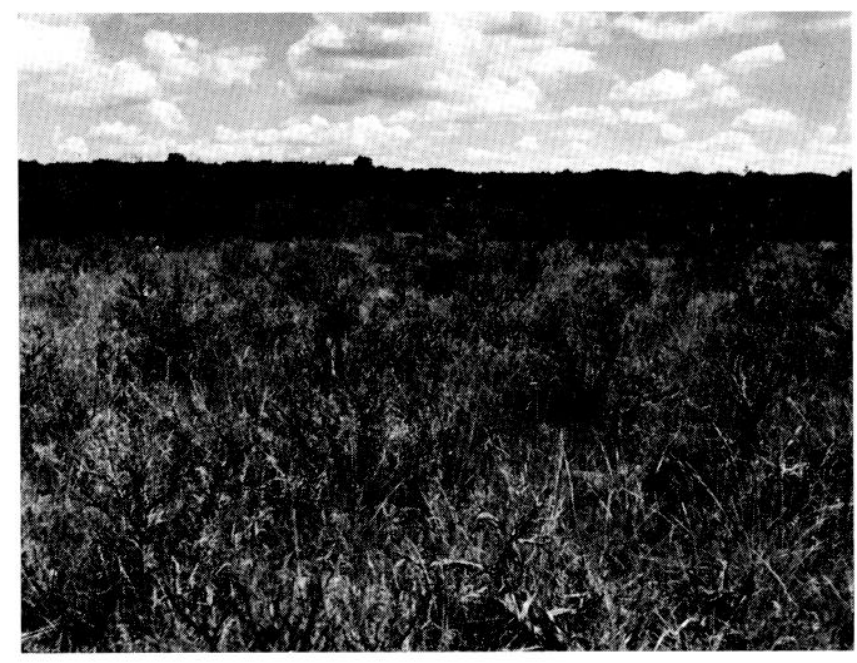

Fig. 3. Sagebrush-grass four years after herbicide treatment (1969 photo).

pounds produced per acre during the grazing season for each pasture.

\section{Results}

Forage production determinations at the end of each grazing season (1966-1970) showed a substantial increase in forage as a result of brush control (Figs. 2, 3, and 4). This relationship of increased forage production held true for each site, but was most evident within the oak thickets (Table 2). Plant composition and forage production was improved on both pastures during the period of this study.

Forage production in the open grassland type was increased $64 \%$ as a result of plant composition changes due to herbicide applications. Forage

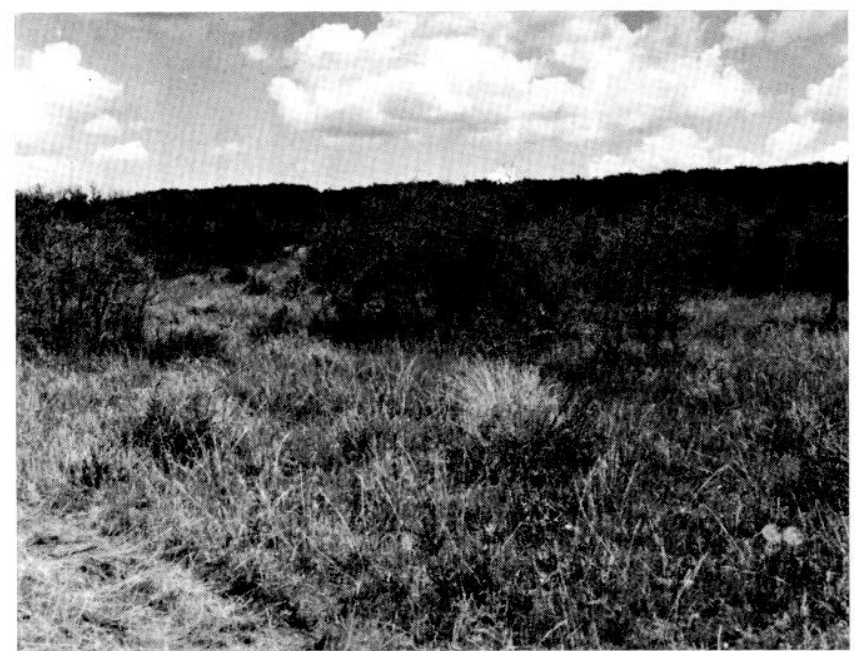

Fig. 4. The oak-grass three years after herbicide treatment (1969 photo).

production in the sagebrush-grass type was increased approximately $81 \%$ after herbicide treatment. Treatment of oak increased the understory forage production $74 \%$ the year following the second application of herbicides.

Five years of grazing results indicate an increase in beef production on the treated Gambel oak pasture. Stocking rate, total gains, and gains per acre increased as a result of increased forage production, reflecting the benefits of brush control practices. There were no significant differences in average daily livestock gains between the treated and untreated pastures (Table 3 ).

Livestock gains were increased by an average of $18 \mathrm{lb}$./acre over a 5 year period as a result of brush

Table 2. Utilization and dry forage produced from treated and non-treated oakbrush pastures from 1966 thru 1970.

\begin{tabular}{|c|c|c|c|c|c|c|c|c|c|c|}
\hline \multirow{2}{*}{$\begin{array}{l}\text { Vegetation } \\
\text { type and } \\
\text { measurement }\end{array}$} & \multicolumn{5}{|c|}{ No brush control } & \multicolumn{5}{|c|}{ Brush control $^{1}$} \\
\hline & 1966 & 1967 & 1968 & 1969 & 1970 & 1966 & 1967 & 1968 & 1969 & 1970 \\
\hline \multicolumn{11}{|l|}{ Open grassland } \\
\hline Utilization $(\%)$ & 54 & 64 & 48 & 60 & 64 & 63 & 69 & 61 & 56 & 67 \\
\hline Forage production (lb.) & 410 & 683 & 1146 & 1088 & 815 & 655 & 851 & 1370 & 1331 & 1335 \\
\hline Production increase attributed to brush control (lb.) & & & & & & 245 & 168 & 224 & 243 & 520 \\
\hline Production increase attributed to brush control $(\%)$ & & & & & & 60 & 25 & 20 & 32 & 64 \\
\hline \multicolumn{11}{|l|}{ Sagebrush-grass } \\
\hline Utilization $(\%)$ & 48 & 50 & 44 & 33 & 50 & 50 & 52 & 55 & 49 & 65 \\
\hline Forage produced per acre (lb.) & 440 & 567 & 884 & 752 & 626 & 562 & 904 & 1363 & 1031 & 1136 \\
\hline Production increase attributed to brush control (lb.) & & & & & & 122 & 337 & 479 & 279 & 510 \\
\hline Production increase attributed to brush control (\%) & & & & & & 28 & 59 & 54 & 37 & 81 \\
\hline \multicolumn{11}{|l|}{ Oakbrush (beneath the canopy) } \\
\hline Utilization (\%) & 50 & 50 & 51 & 26 & 61 & 51 & 44 & 65 & 47 & 62 \\
\hline Forage produced per acre (lb.) & 475 & 424 & 630 & 633 & 762 & 592 & 994 & 1292 & 1101 & 1324 \\
\hline Production increase attributed to brush control (lb.) & & & & & & 117 & 570 & 662 & 468 & 562 \\
\hline Production increase attributed to brush control $(\%)$ & & & & & & 25 & 134 & 105 & 74 & 74 \\
\hline
\end{tabular}


Table 3. Steer days grazed, utilization (\%), and weight gain (lb.) on a non-treated pasture and a brush control treated pasture. ${ }^{1}$

\begin{tabular}{|c|c|c|c|c|c|}
\hline \multirow[b]{2}{*}{ Grazing dated } & \multirow[b]{2}{*}{ Steer days } & \multirow[b]{2}{*}{ Utilization } & \multicolumn{3}{|c|}{ Animal gain } \\
\hline & & & Total & Per day & Per acre \\
\hline \multicolumn{6}{|l|}{ Non-treated pasture } \\
\hline 1966-Iuly 23-Sept. 25 & 435 & 49 & 518 & 1.19 & 20.72 \\
\hline 1967-Aug. 22-Sept. 27 & 324 & 58 & 662 & 2.04 & 26.48 \\
\hline 1968-Aug. 5-Sept. 2 & 392 & 49 & 916 & 2.34 & 36.64 \\
\hline 1969-July 29-Sept. 9 & 420 & 37 & 986 & 2.35 & 39.48 \\
\hline 1970-July 15-Sept. 4 & 510 & 58 & 663 & 1.30 & 26.52 \\
\hline Average & 416 & 50 & 749 & 1.84 & 29.97 \\
\hline \multicolumn{6}{|l|}{ Treated pasture } \\
\hline 1966-July 23-Sept. 9 & 521 & 51 & 838 & 1.63 & 31.04 \\
\hline 1967-Aug. 22-Sept. 27 & 468 & 53 & 930 & 1.99 & 34.44 \\
\hline 1968-Aug. 5-Sept. 2 & 728 & 60 & 1692 & 2.32 & 62.67 \\
\hline 1969-July 29-Sept. 9 & 840 & 50 & 1883 & 2.24 & 69.74 \\
\hline 1970-July 15-Sept. 4 & 1020 & 64 & 1125 & 1.10 & 41.63 \\
\hline Average & 715 & 56 & 1294 & 1.86 & 47.91 \\
\hline
\end{tabular}

${ }^{1}$ The sagebrush was treated in May 1965, the oakbrush treated in June 1966 and July 1969 on the brush control pasture.

control practices. Increased livestock gains in both pastures may be attributed to improved range condition as a result of moderate utilization during the past five years of the study.

\section{Discussion and Conclusions}

Controlling Gambel oak provides more soil moisture for understory forage. Four years of studies have indicated a significant increase in soil moisture during the summer growing season where oak has been controlled. The greatest response in increased soil moisture is at the three to five-foot depths, a zone including numerous oak roots.

The degree of control of Gambel oak is believed a major factor in determining the benefits to be derived from brush control practices. Gambel oak resprouts readily after being disturbed by most methods commonly used to control brush (mechanical, fire, herbicides, etc.). Climatic variations from year to year may play a large role in the different degrees of control.

Increased soil moisture as a result of herbicide application may not be realized where thick oak sprouting occurs, but significant increases in soil moisture are obtained where good control of both mature stems and sprouts is evident. These studies indicate an increase of 4 to $5 \%$ more soil moisture during mid-summer months where oak was totally killed compared to control areas. These conclusions agree with a recent study by Tew in Utah (1969).

Livestock gain per acre was increased as a result of increased forage from herbicide applications. Brush control has nearly doubled the forage production and considerably increased beef production compared to the non-treated oakbrush pasture. Livestock daily gains and gain per acre increased each year until 1970, a year following low winter and spring precipitation. The forage was dry and, although abundant, did not produce the gain on animals as in previous years. However, animal gains per acre were 6 to 10 pounds better in both pastures than five years previous.

Benefits from brush control may be expressed not only as additional forage and returns in beef production, but may bc compared as additional acres of forage available. A summary of five years data indicates a mean requirement of 1.84 acres per steer month on untreated, and 1.22 acres on treated oak pasture ('Iable 4). Thus, for every 1.84 acres of similar pasture, effective control of Gambel oak adds a production equivalent of .62 acre to the grazing land.

Table 4. Mean grazing capacity on untreated and treated brushy rangelands at the San Juan Basin Branch Station.

\begin{tabular}{cc}
\hline Year & $\begin{array}{c}\text { Acres/steer } \\
\text { month }\end{array}$ \\
\hline Untreated & \\
1966 & 1.72 \\
1967 & 2.31 \\
1968 & 1.91 \\
1969 & 1.79 \\
1970 & 1.47 \\
Mean & 1.84 \\
Treated & \\
1966 & 1.55 \\
1967 & 1.73 \\
1968 & 1.11 \\
1969 & .96 \\
1970 & .79 \\
Mean & 1.22 \\
\hline
\end{tabular}




\section{Literature Cited}

Astatke, H. 1967. Oak defoliation and understory plants. M. S. thesis. Colorado State Univ. 62 p.

Brown, H. E. 1958. Gambel oak in west-central Colorado. Ecology 39:317-327.

Christensen, E. M. 1949. The ecology and geographic distribution of oakbrush (Quercus gambelii) in Utah. M. S. thesis. Univ. of Utah. $70 \mathrm{p}$.

JefFeries, N. W., AND J. J. NoRris. 1965. Management and improvement of Gambel oak ranges. Colorado Agr. Exp. Sta. PR 147. 2 p.

Johnson, W. M. 1953. Effect of grazing intensity upon vegetation and cattle gains on Ponderosa pine-bunchgrass ranges of the Front Range of Colorado. U.S. Dep. Agr. Circ. No. $929.36 \mathrm{p}$.

MARQuiss, R. W. 1969. Studies on Gambel oak at the San Juan Basin Branch Station. Colorado Agr. Exp. Sta. PR 69-38. 2 p.

Molnat, A. D. 1956. Comparative yields of herbage from oak scrub and interspersed grassland in Colorado. Ecology $27: 852-854$.

Tew, R. D. 1966. Soil moisture depletion by Gambel oak in northern Utah. U.S. Forest Serv. Res. Note INT54. $7 \mathrm{p}$.

TEw, R. D. 1969. Converting Gambel oak sites to grass reduces soil moisture depletion. U.S. Forest Serv. Res. Note INT-104. $4 \mathrm{p}$. 